University of Nebraska - Lincoln

DigitalCommons@University of Nebraska - Lincoln

Textile Society of America Symposium

Proceedings

Textile Society of America

$10-2020$

Glitched Metaphors: Dysfunction in Hand-Woven Digital Jacquard

Gabe Duggan

Follow this and additional works at: https://digitalcommons.unl.edu/tsaconf

Part of the Art and Materials Conservation Commons, Art Practice Commons, Fashion Design Commons, Fiber, Textile, and Weaving Arts Commons, Fine Arts Commons, and the Museum Studies Commons

This Article is brought to you for free and open access by the Textile Society of America at DigitalCommons@University of Nebraska - Lincoln. It has been accepted for inclusion in Textile Society of America Symposium Proceedings by an authorized administrator of DigitalCommons@University of Nebraska - Lincoln. 
Published in Hidden Stories/Human Lives: Proceedings of the Textile Society of America 17th Biennial Symposium, October 15-17, 2020. https://digitalcommons.unl.edu/tsaconf/ Copyright @ 2020 Gabe Duggan doi: $10.32873 /$ unl.dc.tsasp.0087

\section{Glitched Metaphors: Dysfunction in Hand-Woven Digital Jacquard Gabe Duggan}

"To glitch is to embrace malfunction, and to embrace malfunction is in and of itself and expression that starts with 'no'.",

This is not digital, this is not weaving. Oscillating between technologies hand and machine, one learns how to challenge and work with one, based on experiences with the other.

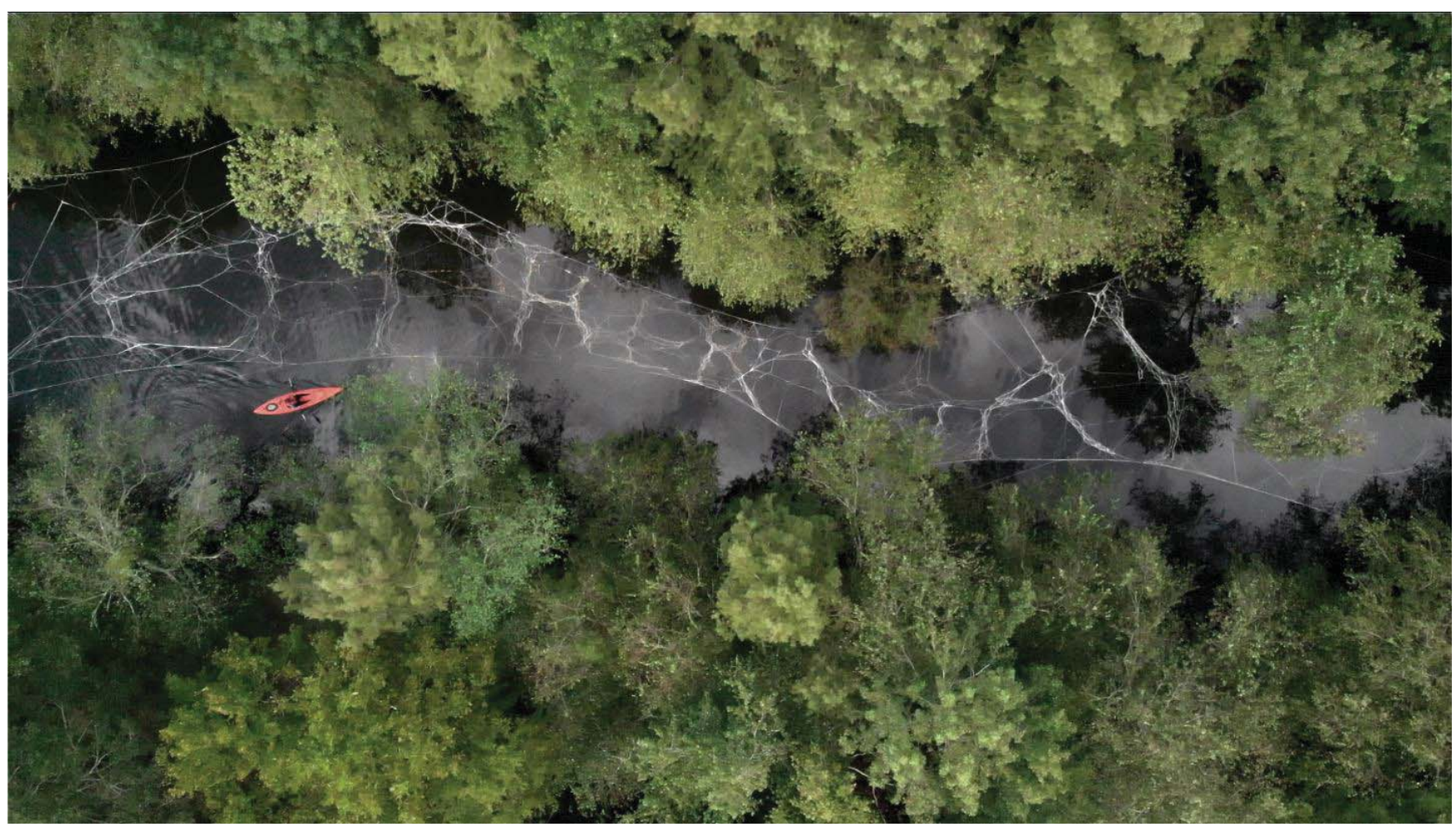

EITHERWAY, 2020; 40 X 300 ft., DSMdyneema; Installed, documented, and deinstalled August 2020 at Wildside water on Tuscarora/Skaruhreh land in Eastern North Carolina. Non extent; collection of author

This is suspension, tension, order of chaos; a weaver's strategies. It is digital at every inherently/inevitably binary intersection through space, almost tyrannical in its simple rule that at every meeting there can, must always only ever be, -one- on top, only one winner. Cut and dry. It is also digital in its only form of existence.

"The inefficiencies of a network - all that redundancy and ricocheting vectors, things going from here to there and back just to get across the street- encompasses imperfection rather than ejecting it. A network nurtures small failures in order that large failures don't happen as often. It is its capacity to hold error rather than scuttle it that makes the distributed being fertile ground for learning, adaptation, and evolution."2

1 Legacy Russell, Glitch Feminism: A Manifesto (London, UK: Verso Books, 2020), 17.

2 Kevin Kelly, Out Of Control: The New Biology Of Machines, Social Systems, And The Economic

World. (United Kingdom: Basic Books, 1994), 24. 
It would help to define technologies here. For our purposes, let us say that technology is anything between the thought and the material (Making Real; IRL). "Between" can be a hurdle or a conduit; bridges and walls both define between. Under this definition falls digital data, machines, the hand, body $^{3}$, and interference data such as memories, aches, and pleasure.

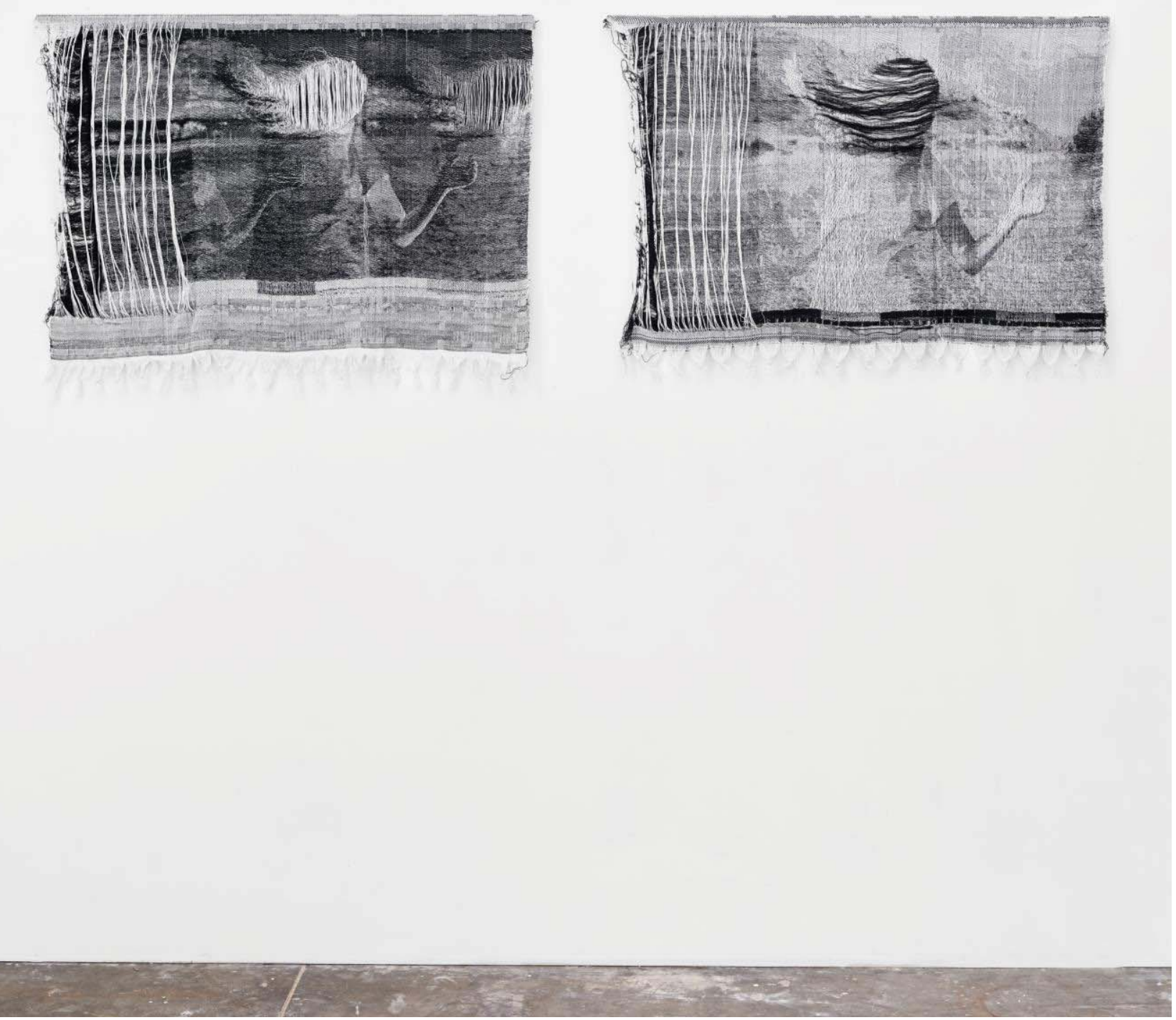

'honeystillfloats', 2019; (diptych) 38 X 24 inches each; cotton, polymer fibers Handwoven digital jacquard; a still of a video performed outside Big Bend/Marfa, TX. Inverted with intentional and unpredicted glitches expressing a negotiation with a machine breaking down as it facilitates weaving; collection of author

"This cost a lot," she said, extending her right hand as thought it held an invisible fruit. The five blades slid out, then retracted smoothly. "Costs to go to Chiba, costs to get the surgery, costs to have them jack your nervous system up so you'll have the reflexes to go with the gear... You know how I got the money, when I was starting out? Here. Not here, but a place like it, in the Sprawl. Joke, to start with, 'cause once they plant the cut-out chip, it seems like free money. Wake up sore, sometimes, but that's it. Renting the goods, is all. You aren't in, when it's happening. House has software for whatever a customer wants to pay for..." She cracked her

3 Gabe Duggan, "Stick and Stone," (Cooper Hewitt Object of the Day, last modified September 16, 2018) https://www.cooperhewitt.org/2018/09/16/stick-and-stone/. 
knuckles. "Fine. I was getting my money. Trouble was, the cut-out and the circuitry the Chiba clinics put in weren't compatible. So worktime started bleeding in, and I could remember it..."4

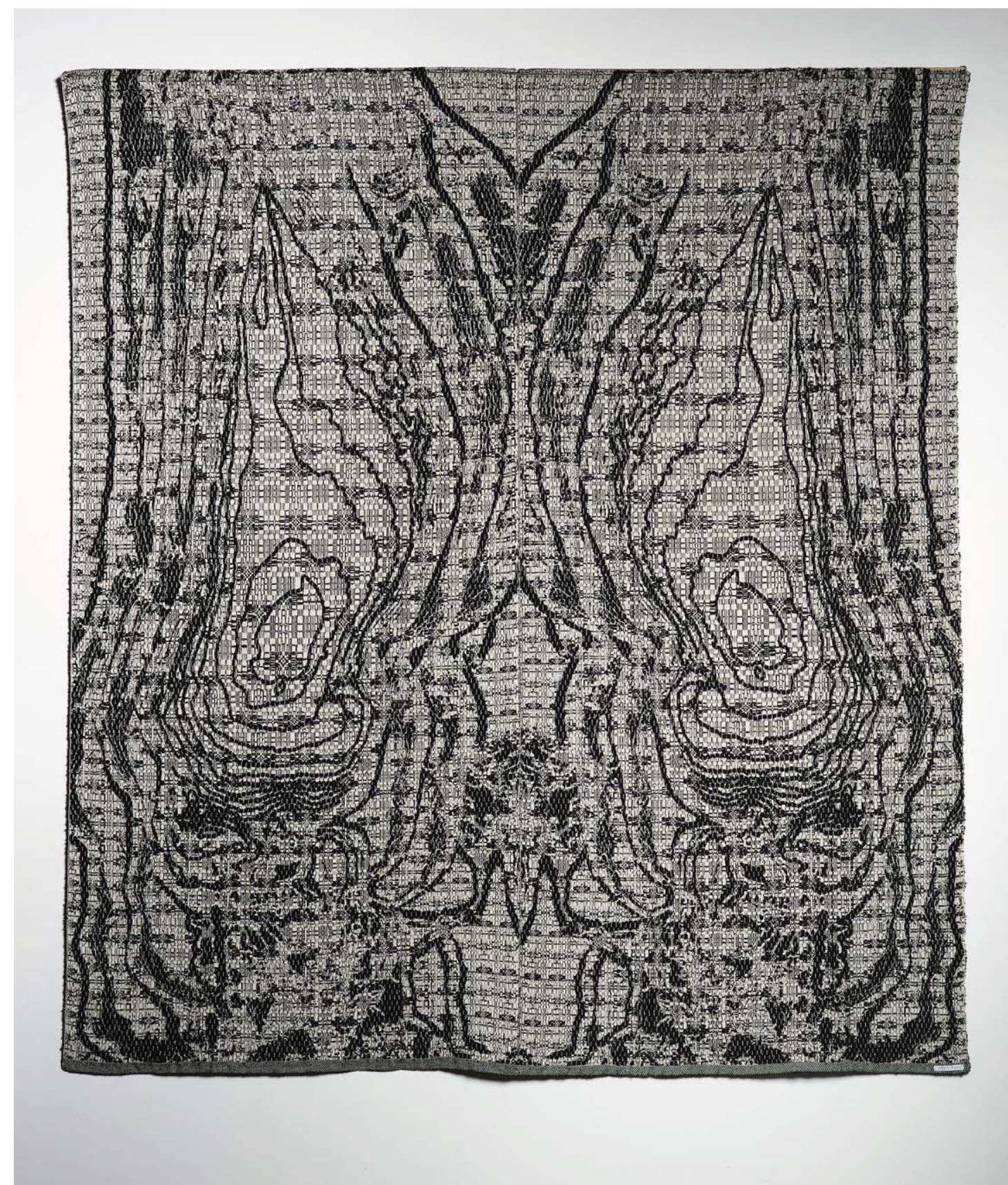

'lakewise', 2017; 80 X 88 inches; cotton, wool; 'lakewise' is a coverlet embodying traditions of overshot weaving, digital systems, and bathymetry (Lake Erie) to construct a functional object for osmosis; collection of author

Does symmetry reflect not just self, but the Binary at its core? In its duplicitous mirror holding, are these compositions inherently dichotomous- do these feed a larger dichotomy? Some technologies are just bi- enough, dancing a three-legged waltz with function, dysfunction, and collaborator. This graceful, rhythmic falling between half-on, half-off, and thirdspace balances momentarily just enough to hold law and freedom, unenforced law and nature's anarchy within one piece.

4 William Gibson, Neuromancer. (New York, NY: Ace Books, 1986), 147. 


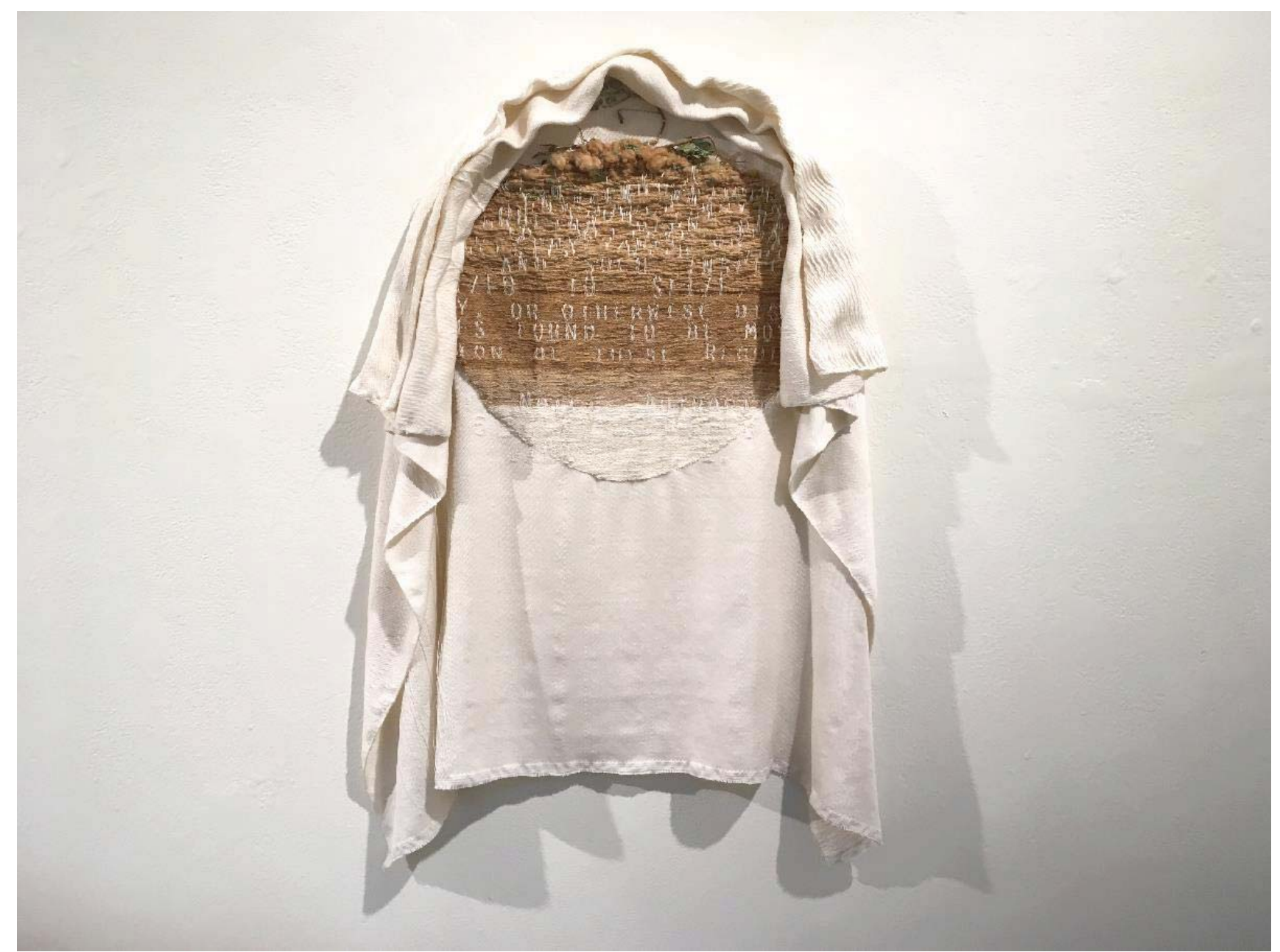

'Cottonweed', 2017; 4 X 32 X 38 inches, commercial/industrial and undocumented/heritage cotton; Handwoven digital jacquard with 02NCAC48A.0607 excerpt; laws controlling cotton growing in North Carolin; collection of author

We fuse. The words spill out from code bound by pixel, reliant on thread built from plants that have bent themselves to our species' insatiability, a desire that rendered logical kidnapping, enslaving, country and culture splitting, and re-founding on scar material alone. And yet regardless of the blood we wipe on this plant, or how we spin them disposable, they grow. They reseed, they get preyed on by weevils, beyond our myopic needs/desires/gaze.

"That is the fundamental nature of gifts: they move, and their value increases with their passage. The fields made a gift of berries to us and we made a gift of them to our (parent). The more something is shared, the greater its value becomes."

"In material fact, Strawberries belong only to themselves. The exchange relationships we choose determine whether we share them as a common gift or sell them as a private commodity. A great deal rests on that choice. For the greater part of human history, and in places in the world today, common resources were the rule. But some invented a different story, a social construct in which everything is a commodity to be bought and sold. The market economy story has spread like wildfire, with uneven results for human well-being and devastation for the natural world. But it is just a story we have told ourselves and we are free to 
tell another, to reclaim the old one."5

My work on the TC1/TC2 digital jacquard loom has primarily been tethered to one specific machine with which I have shared a personal past and future for just over a decade. This particular machine's trajectory echoes the precarity of many people and practices ${ }^{6}$ within dominant institutions. Through this technology I have built and negated tension, challenging a broad range of power dynamics.

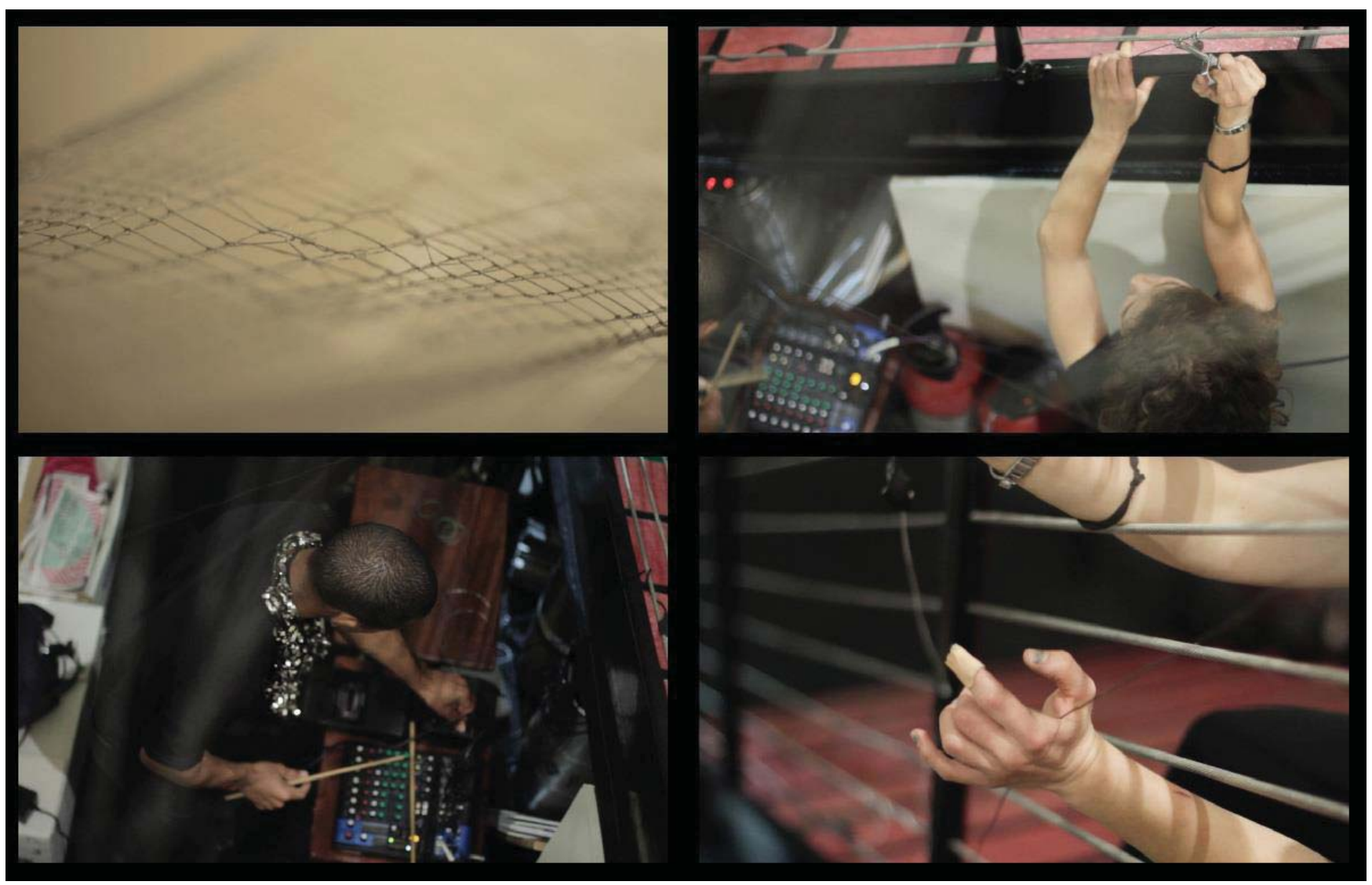

'Resound', 2015; 8 X10 X 22 feet; Sound performance in collaboration with Nic Jenkins. Installed for Indie Grits Film Festival in Columbia, SC; collection of author

Tension pulsates through space, into surrounding bodies through soundwaves. Tension builds, destroys, tension gives, holds. What is this tension? What's to be done with all this tension? It brings its own decay, demise. It turns on itself, a merciless critical lens, a too accurate scalpel. What are its origins, where does it lead, point us to? (In the practice of draping, wrinkles always point to the problem.)

When I talk to the machine, who am I talking to, "Who is there"? Where do these prayers go? No one is listening and I continue talking.

"Hidden in the Net is the mystery of the Invisible Hand- control without authority."7

5 Robin Wall Kimmerer, Braiding Sweetgrass, (Minneapolis MN: Milkweed Editions, 2013), $27,31$.

6 Devin Rardin, "UNT Fibers Students Speak Out on the Closing of Fibers Program," (North Texas Daily last modified August 23, 2018), https://www.ntdaily.com/unt-fibers-students-speak-out-on-the phasing-out-of-the-fibers-program/

7 Kelly, Out of Control, 26. 


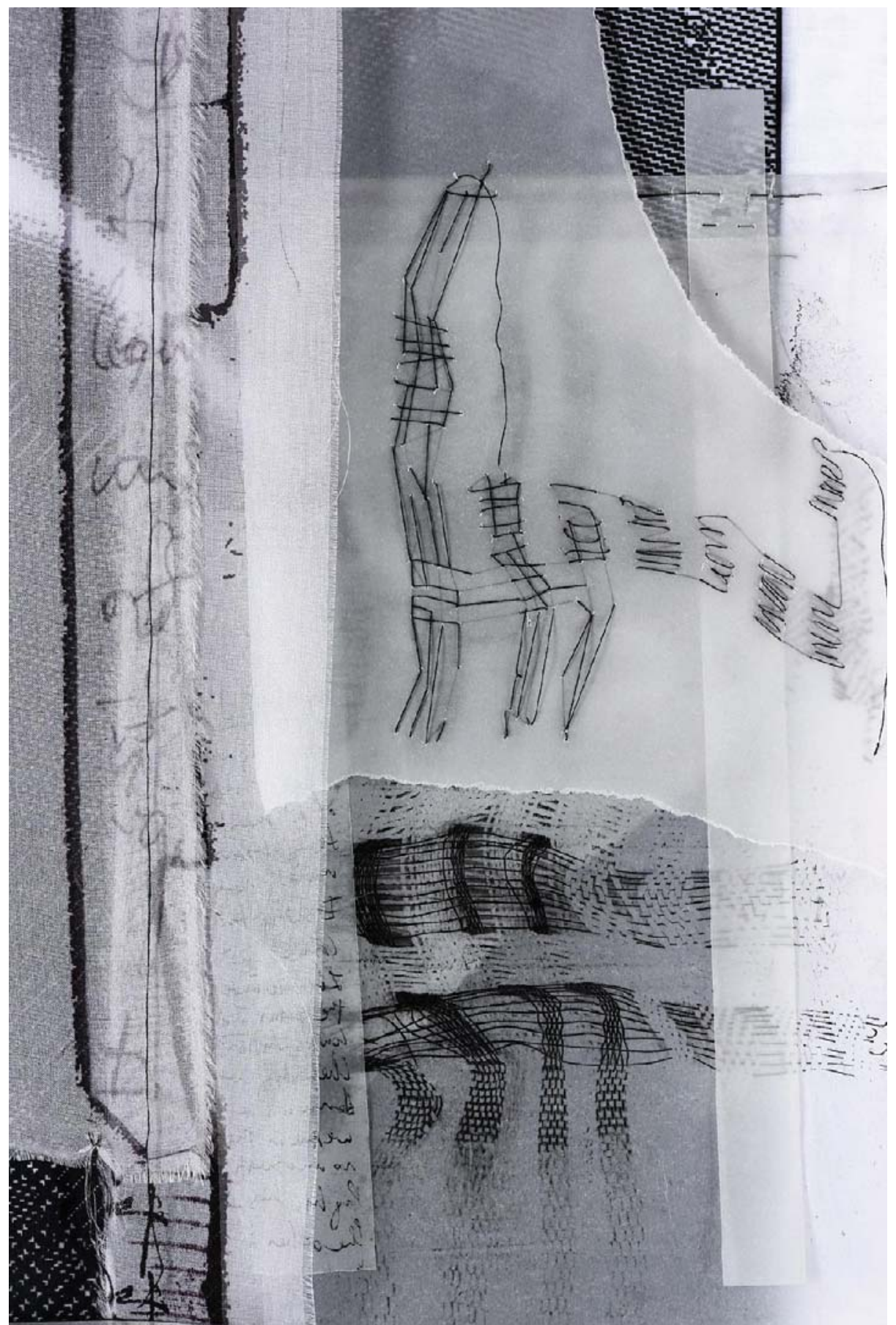

'beach hairs', 2019 (detail) 22 X 36 inches; cotton, silk, paper, synthetic fibers; A selfie manipulated into digital jacquard draft; pixels used to represent individual threads are printed onto threads of industrially woven cloth. Additional implications are made through surface and structural renderings; collection of author

Replicas and Access: When we turn it in on itself, what comes out the other end? How many selfreferences can we make until we fully disintegrate? (halflife. Parabolic, asymptotic.) 
"Cyborgs are not reverent; they do not remember the cosmos.

"The main trouble with cyborgs is that they are...illegitimate offspring...But illegitimate offspring are often exceedingly unfaithful to their origins."

What if we just click 'print'? (Why not, just click, 'print'...?) Let's invite the grid to receive its replica.

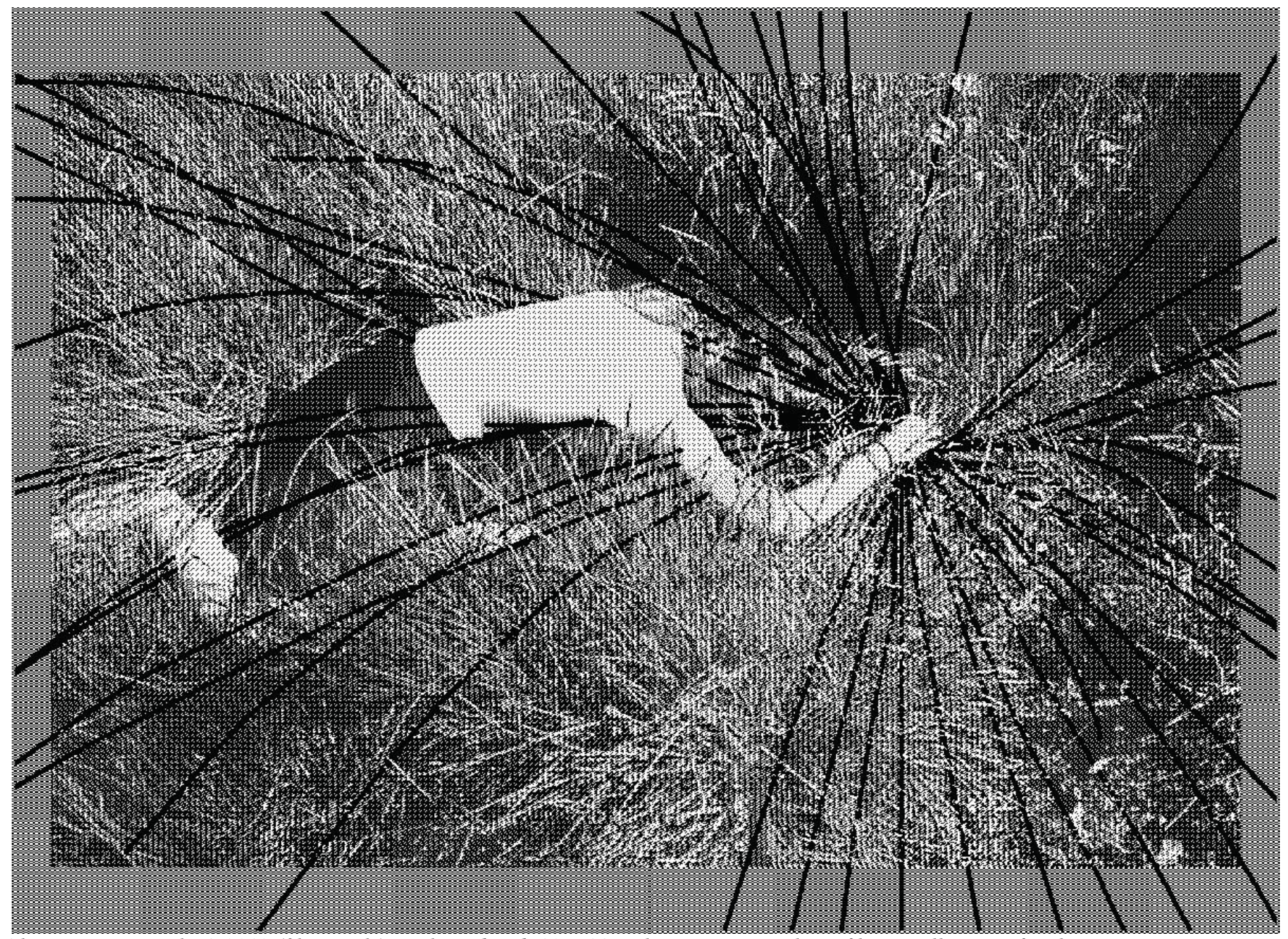

'there are no mistakes', 2012 (file; pixels) Work rendered: 32 X 38 inches; cotton, synthetic fibers; collection of author

Inefficiencies are the colleagues that close the door to your office behind them on your first day; who rapid-fire email asking if you're on campus can you meet up; who email repeatedly after lam about some unsolicited music video; the senior colleague that intoxicatedly accosts at a restaurant where you went to catch up on articles, or who yells without ceasing at another in a meeting; the supervisor who wishes you a relaxing vacation after you explain the connection is slim at your residency, which is the mainline of your research in which you are staying in a chicken coop amidst piles of compost and ag. equipment so that you can wake up and sweat in the field all day, everyday, pushing up against the question, 'do you have enough time to accomplish what you came to do?'

8 Donna Haraway, "A Cyborg Manifesto: Science, Technology, and Socialist-feminism in the Late Twentieth Century," Socialist Review (1985), 293. 


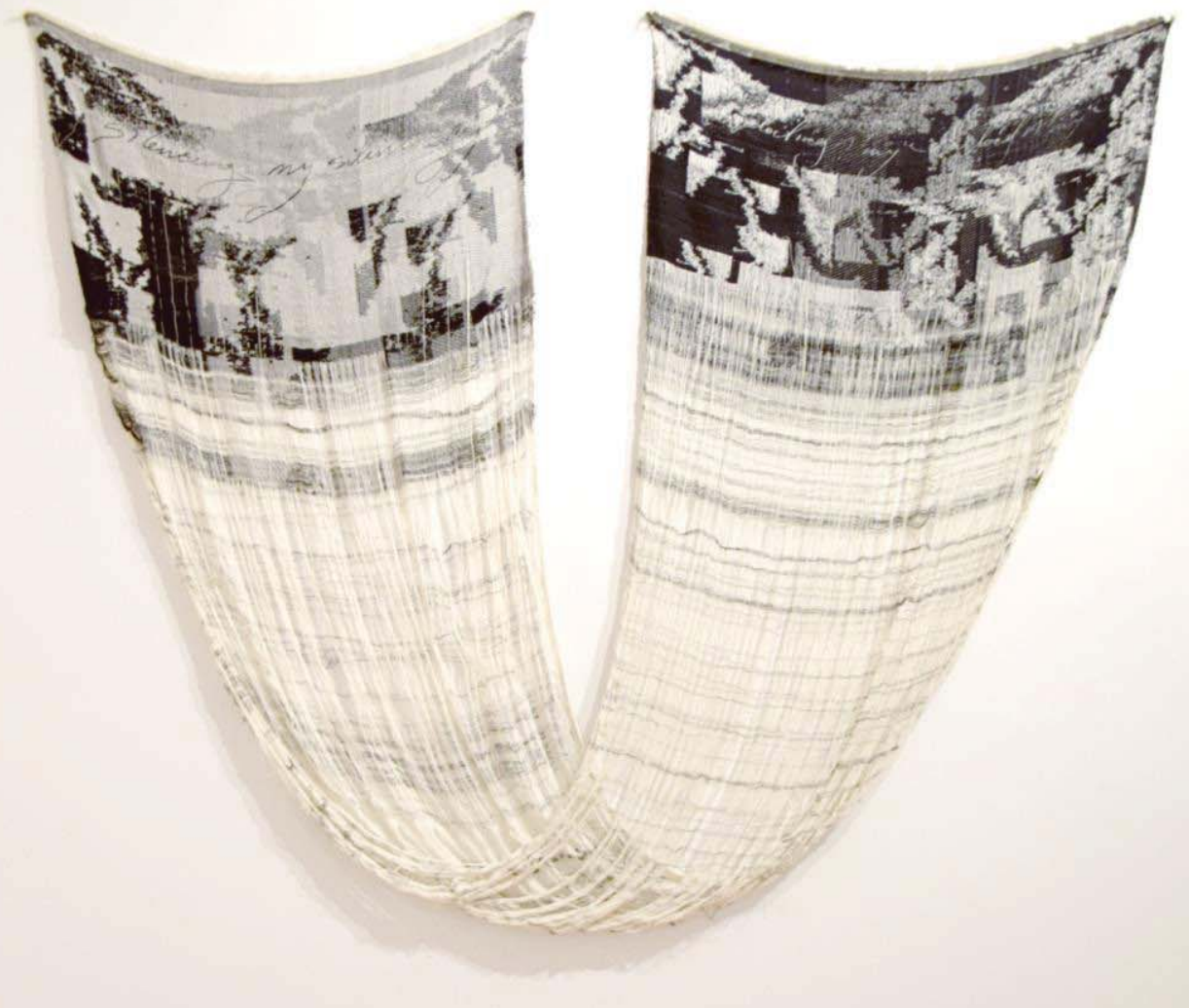

'AsOne', 2017 (conjoined diptych) 38 X 56 inches each; cotton and polymers; Handwoven digital jacquard depicting double standards within a self-directed artistic practice: "silencing my silencing, exploiting my exploitation"; collection of author

Inefficiencies are the mentors who bind you in various ways, physically, mentally, professionally, so that they can ignore your repeated 'no's.

But these are just the seed moments of inefficiencies that grow into hours of tiptoeing around labyrinths of missing stairs; of cashing in on pro-bono consultation from family and friends and paid counsel, too; of self-prescribing exercise and the occasional frivolous purchase to steal yourself back into the present; of doing the endless invisible homework trying to track down what can possibly be advised to your own mentees that are in line to inherit all this, what hope could possibly remain. ${ }^{9}$

9 Cliff Pervocracy, “The Missing Stair,” (The Pervocracy, last modified June 22, 2012) http://pervocracy.blogspot.com/2012/06/missing-stair.html. 

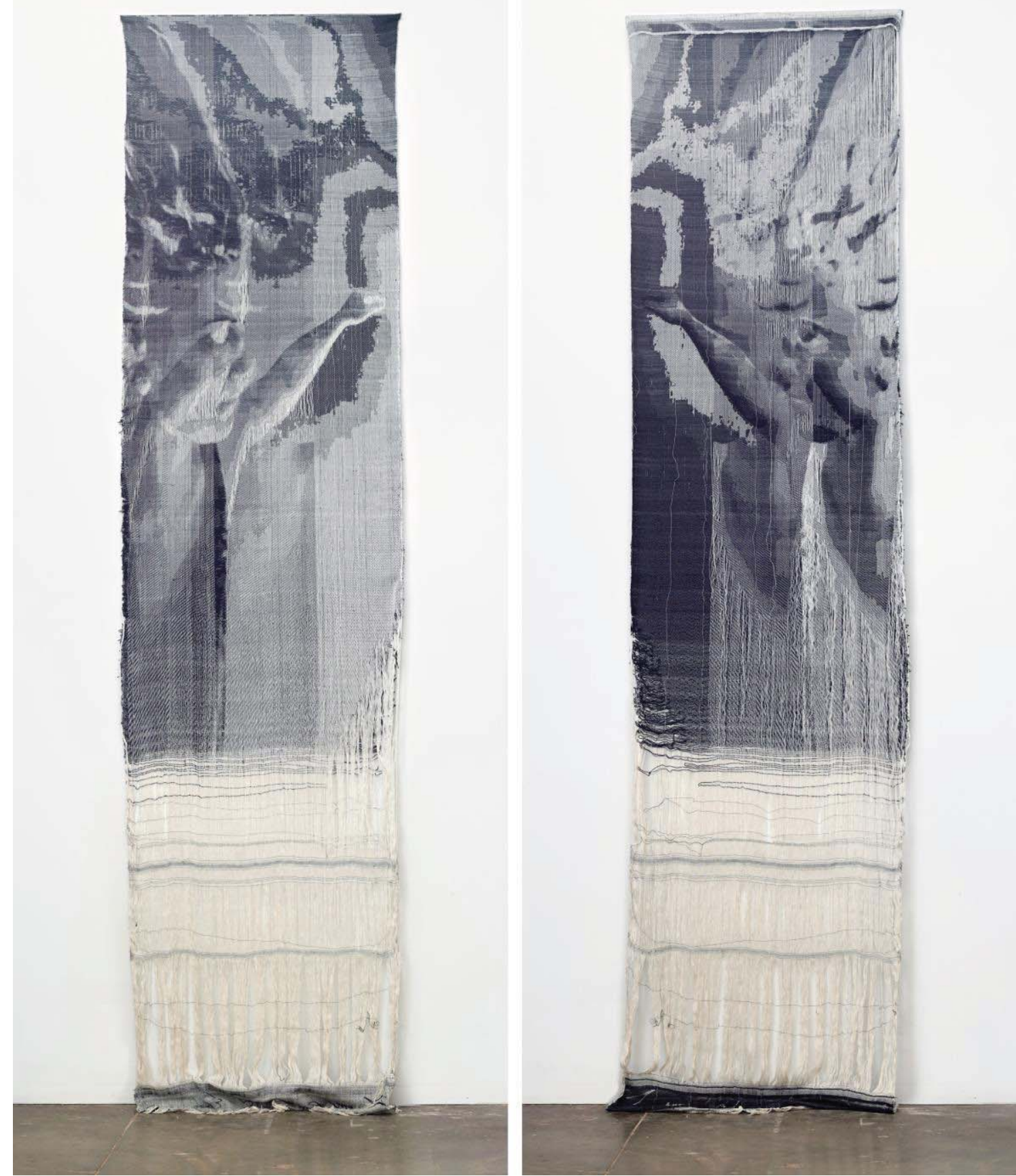

'weaving2018,' 2019; (both sides) 38 X 145 inches; cotton, polymer fibers

Digital jacquard hand woven on a TC1 glitching due to neglect; collection of author

All these hours taking you away from sleep, from the very work itself. From health and self and others.

"In order to know who we are- to have an identity- we must know (or at least feel that we know) what is and what was "real"."

"Erasing awareness and cultivating denial are often essential to survival..."10

10 Bessell van der Kolk, The Body Keeps the Score: Brain, Mind, and Body in the Healing of Trauma, (New York: Penguin Books, 2015), 136. 
Is this a tool that is resilient, adaptable, like you or me enough to hold inefficiencies and not fall apart?



What can we learn from dysfunction? What is the function of Function, what is the use? In a nonfunctional object? An object whose one function is to receive/absorb/be a receptacle for the gaze? In a dysfunctional system? To feed, contribute to, a system mid-crumble, a system exploiting, even parasiting off of this feed, this voluntary, opting-in, self-subscribing feeder?

"I had been told all my life that this was a good and necessary thing Tlic and Terran did together- a kind of birth. I knew birth was painful and bloody, no matter what. But this was something else, something worse. And I wasn't ready to see it. Maybe I never would be. Yet I couldn't not see it. Closing my eyes didn't help. T'Gatoi found a grub still eating its egg case. The remains of the case were still wired into a blood vessel by their own little tube or hook or whatever. That was the way the grubs were anchored and the way they fed. They took only blood until they were ready to emerge. Then they ate their stretched, elastic egg cases. Then they ate their hosts. T'Gatoi bit away the egg case, licked away the blood. Did she like the taste? Did childhood habits die hard- or not die at all? The whole procedure was wrong, alien. I 
wouldn't have thought anything about her could seem alien to me."11

Is this an order that is careening towards dishevelment, dismantling, a natural chaos? Where is the fulcrum, the balance, the tipping point between function and dysfunction? In systems that are optimally functioning, is the human body not posited as the most significant, perhaps sole remaining, resiste(o)r?

Is high-functioning enough? Who does “divergence," "emergence," or "typicality" serve?

Does this matter? Is the end only asymptotic; forever reaching but never arriving- not a big bang, but a slow boil?

"In the fraying of identities and in the reflexive strategies for constructing them, the possibility opens up for weaving something other than a shroud for the day after the apocalypse that so prophetically ends salvation history."12

Even the prepper's death-grip loosens with revelation, Cassandra lets her hair down. The one remaining currency boils down to animal needs, animal haves. We continue envisioning distance between us and this tether to physicality, self-soothing through the pixel, an infinite vector. 


\section{Bibliography}

Butler, Octavia E. Bloodchild and Other Stories. New York, NY: Seven Stories Press, 2011.

Duggan, Gabe. "Stick and Stone", Cooper Hewitt Object of the Day, last modified September 16, 2018, https://www.cooperhewitt.org/2018/09/16/stick-and-stone/.

Gibson, William. Neuromancer. New York, NY: Ace Books, 1986.

Haraway, Donna. “A Cyborg Manifesto: Science, Technology, and Socialist-feminism in the Late Twentieth Century." Socialist Review (1985).

Kelly, Kevin. Out Of Control: The New Biology Of Machines, Social Systems, And The Economic World. United Kingdom: Basic Books, 1994.

Kimmerer, Robin Wall. Braiding Sweetgrass. Minneapolis MN: Milkweed Editions, 2013.

Pervocracy, Cliff. “The Missing Stair”, The Pervocracy, last modified June 22, 2012 http://pervocracy.blogspot.com/2012/06/missing-stair.html.

Rardin, Devin. "UNT Fibers Students Speak Out on the Closing of Fibers Program”, North Texas Daily last modified August 23, 2018, https:/www.ntdaily.com/unt-fibers-students-speak-out-on-the phasing-out-of-the-fibers-program/.

Russell, Legacy. Glitch Feminism: A Manifesto. London, UK: Verso Books, 2020.

van der Kolk, Bessell. The Body Keeps the Score: Brain, Mind, and Body in the Healing of Trauma. New York, NY: Penguin Books, 2015 